\title{
PELATIHAN KURIKULUM 2013 DI TINGKAT SEKOLAH DASAR
}

\author{
R. Mekar Ismayani ${ }^{1}$, Diena San Fauziya ${ }^{2}$ \\ IKIP SILIWANGI \\ 1mekarismayani@ikipsiliwangi.ac.id, 2diena@ikipsiliwangi.ac.id
}

\begin{abstract}
ABSTRAK
Pergantian kurikulum dari Kurikulum Tingkat Satuan Pendidikan (KTSP) atau selanjutnya disebut kurikulum 2006 ke kurikulum 2013 menimbulkan polemik di kalangan sekolah baik di tingkat sekolah dasar maupun tingkat sekolah menengah. Banyak guru yang masih kebingungan dalam pengimplementasian kurikulum 2013 ini. Di tingkat sekolah dasar dan sederajat seperti Madrasah Ibtidaiyah (MI) pembelajaran menjadi bersifat tematik (terpadu). Belum lagi bentuk evaluasi yang mengintegrasikan penilaian sikap dan kognitif yang harus dilakukan pada setiap proses pembelajaran hal itu menyulitkan para guru terutama sekolah yang dalam satu kelas termasuk ke dalam katagori kelas gemuk. Artikel ini membahas hasil kegiatan pengabdian pada masyarakat (PPM) yang dilaksanakan pada tanggal 21 Juli 2014. Pelatihan ini dilakukan dengan sasaran guru-guru MI Darul Furqon Lembang dengan tujuan agar guru mendapat pencerahan dan tambahan wawasan dalam pengimplementasian kurikulum 2013 mulai dari perencanaan (penyusunan RPP dan jadwal) pelaksanaan proses pembelajaran tematik, dan penilaian. Dengan dilaksanakan pelatihan ini secara tidak langsung meningkatkan kompetensi guru dalam pengimlementasian kurikulum 2013.
\end{abstract}

Kata Kunci: kurikulum 2013, tingkat sekolah dasar, pembelajaran tematik

\begin{abstract}
Substitution of the curriculum from the Education Unit Level Curriculum (KTSP) or hereinafter referred to as the 2006 curriculum into the 2013 curriculum raises polemics among schools at both the elementary and secondary levels. Many teachers are still confused in implementing this 2013 curriculum. At the elementary school level and in the same level as Madrasah Ibtidaiyah (MI) learning becomes thematic (integrated). Not to mention the form of evaluation that integrates attitude and cognitive assessment that must be done in each learning process that makes it difficult for teachers, especially schools, which in one class belong to the category of fat class. This article discusses the results of community service activities which was held on July 21,2014 . The training was conducted with the aim of MI Darul Furqon Lembang teachers with the aim that teachers get enlightenment and additional insights in implementing the 2013 curriculum starting from planning (preparation of learning and schedule) the implementation of thematic learning processes, and assessments. By conducting this training indirectly increasing teacher competency in the 2013 curriculum implementation.
\end{abstract}

Keywords: curriculum in 2013, elementary schools, thematic learning

\section{A. PENDAHULUAN}

Pendidikan saat ini sedang mendapat sorotan yang tajam. Hal ini berkenaan dengan berganti laginya kurikulum yang berlaku. Setelah KTSP digunakan kurang lebih tujuh tahun, kini pemerintah menetapkan kebijakan bahwa kurikulum yang berlaku adalah kurikulum 2013. Sosialisasi mengenai kurikulum ini telah dilakukan dengan berbagai macam upaya, di antaranya setiap perwakilan sekolah diberikan diklat dan pelatihanpelatihan agar memiliki pemahaman dan keterampilan dalam menerapkan kurikulum 2013 untuk semua tingkatan pendidikan. Sayangnya, diklat dan pelatihan-pelatihan 
belum mampu memberikan pemahaman yang cukup bagi sekolah untuk menerapkan kebijakan baru ini.

Kebelumsiapan sekolah dalam menerapkan kurikulum 2013 terbukti dari adanya undangan kepada kami untuk dapat memberikan pelatihan bagi guru-guru, khususnya di MIS Darul Furqan Lembang. Melalui undangan dari Ibu Dian Novita dan Bapak Ucu, kami melaksanakan pengabdian dengan tema "pelatihan kurikulum 2013".

Adapun rumusan masalah dalam pengabdian ini adalah bagaimana persiapan penerapan kurikulum 2013 di Madrasah Ibtidaiyah?

\section{B. LANDASAN TEORI}

\section{Kurikulum 2013}

Kurikulum 2013 dipandang sebagai kurikulum baru yang jauh berbeda dengan kurikulum sebelumnya. Padahal, kurikulum ini tidak sepenuhnya baru. Kurikulum 2013 merupakan kurikulum penyempurna dari kurikulum-kurikulum sebelumnya. Meskipun mendatangkan pro dan kontra, perubahan ini bersifat wajar karena ilmu pengetahuan dan teknologi juga berubah dari waktu ke waktu.

Terdapat setidaknya empat elemen perubahan kurikulum dalam kurikulum 2013 untuk setiap tingkatan, termasuk tingkat sekolah dasar (SD/MI). Elemen perubahan itu terjadi pada standar kompetensi lulusan, standar isi, standar proses, dan standar penilaian.

Untuk setiap tingkatan, termasuk SD, elemen perubahan dalam standar kompetensi lulusan terjadi dengan adanya peningkatan dan keseimbangan antara soft skills dan hard skills yang meliputi aspek kompetensi sikap, keterampilan, dan pengetahuan. Sesungguhnya, ketiga aspek tersebut memang sudah dimunculkan dalam kurikulum tingkat satuan pendidikan, namun tidak serta merta menjadi fokus utama yang sama karena dalam KTSP sebagai kurikulum sebelumnya aspek pengetahuan lebih diutamakan dibandingkan aspek lainnya. Dalam kurikulum 2013 ini, aspek kompetensi sikap, keterampilan, dan pengetahuan menjadi fokus yang sama-sama penting/setara.

\section{Tematik dalam Kurikulum SD}

Kurikulum SD dikembangkan dengan menekankan tematik dalam setiap pembelajaran. Poerwadarminta dalam Majid (2014:80) mengemukakan pembelajaran tematik merupakan pembelajaran terpadu yang menggunakan tema untuk mengaitkan beberapa mata pelajaran sehingga dapat memberikan pengalaman bermakna kepada 
murid. Tema adalah pokok pikiran atau gagasan pokok yang menjadi pokok pembicaraan.

Dalam tayangan implementasi pembelajaran tematik terpadu yang disusun kemdikbud (2013b) diuraikan banyak hal mengenai pembelajaran tematik. Beberapa di antaranya mengenai ciri pembelajaran tematik, yakni: 1) berpusat pada anak; 2) memberikan pengalaman langsung; 3) pemisahan antar mata pelajaran tidak nampak; 4) menyajikan konsep dari beberapa mata pelajaran dalam satu PBM; 5) bersifat luwes; dan 6) hasil pembelajaran dapat berkembang sesuai dg minat dan kebutuhan anak.

\section{Model Pembelajaran dalam Implementasi Kurikulum 2013}

Kegiatan pembelajaran berdasarkan kurikulum 2013 dilakukan dengan megacu pada pendekatan saintifik. Kegiatan pembelajaran dengan penerapan saintifik ini selanjutnya dapat dikembangkan dengan beberapa model pembelajaran. Dalam kurikulum 2013, terdapat setidaknya tiga model pembelajaran yang dapat digunakan, yakni model pembelajaran penemuan (discovery), pembelajaran berbasis masalah (problem based learning), dan pembelajaran berbasis proyek (project based learning).

\section{Evaluasi Pembelajaran dalam Implementasi Kurikulum 2013}

Evaluasi pembelajaran dalam implementasi kurikulum 2013 ini dilakukan dengan penilaian autentik. Jika kembali melihat kurikulum sebelumnya (KTSP), sebetulnya kurikulum tersebut telah menyinggung-nyinggung dan bahkan menetapkan penilaian autentik sebagai penilaian yang harus dilakukan. Namun, kenyataannya penilaian tersebut belum diimplementasikan secara optimal di lapangan. Dengan demikian, dalam kurikulum 2013 ini penilaian autentik kembali menjadi fokus penilaian.

Penilaian autentik itu sendiri merupakan jenis penilaian yang menilai siswa dalam keadaan yang sebenarnya. Artinya, dalam penilaian autentik kondisi siswa betul-betul dinilai secara nyata dan apa adanya. Kunandar (2013:37) menerangkan bahwa dalam penilaian autentik peserta didik menampilkan atau mengerjakan suatu tugas atau proyek. Lebih lanjut ia menerangkan bahwa pada penilaian autentik kemampuan berpikir yang dinilai adalah level konstruksi dan aplikasi serta fokusnya pada peserta didik. Hal ini tentu saja berbeda dengan penilaian tradisional yang biasanya digunakan, yakni kemampuan berpikir yang dinilai cenderung pada level memahami dan fokusnya adalah guru.

Dalam pembelajaran di sekolah dasar, penilaian autentik ini sangat tepat digunakan karena sangat relevan dengan pendekatan tematik terpadu yang menjadi pendekatan 
pembelajarannya. Melalui penilaian autentik, keseimbangan antara aspek afektif, psikomotorik, dan pengetahuan dinilai secara jelas. Meskipun demikian, dalam proses pembelajaran di tingkat sekolah dasar, aspek afektif menjadi fokus utama karena pada dasarnya tahap ini merupakan pembentukkan fondasi sikap agar peserta didik siap melanjutkan pendidikan ke jenjang yang lebih tinggi untuk memperdalam kompetensi pengetahuan dan keterampilan.

Ciri-ciri penilaian autentik menurut Kunandar (2013:38-39) adalah sebagai berikut. 1. Harus mengukur semua aspek pembelajaran; 2. Dilaksanakan selama dan sesudah proses pembelajaran; 3. Menggunakan berbagai cara dan sumber; 4. Tes hanya salah satu alat pengumpul data penilaian; dan 5. Tugas-tugas yang diberikan kepada peserta didik harus mencerminkan bagian-baian kehidupan peserta didik yang nyata.

\section{Penyusunan Rencana Pembelajaran}

Kurikulum 2013 merupakan kurikulum yang disebut-sebut sebagai kurikulum siap pakai. Isu ini muncul sekaitan dengan telah disiapkannya segala macam panduan kebutuhan belajar mengajar, mulai dari silabus hingga buku teks. Meskipun demikian, rencana pembelajaran yang bersifat praktis, yakni yang dikenal dengan istilah RPP (Rencana Pelaksanaan Pembelajaran) tetap harus disusun oleh guru yang bersangkutan.

Permendikbud No. 81A tentang Implementasi Kurikulum 2013 menguraikan segala bentuk prosedur yang dibutuhkan sebagai panduan implemetasi kurikulum baru ini, termasuk penyusunan RPP. Dalam permendikbud tersebut diuraikan langkah-langkah penyusunan adalah RPP sebagai berikut: 1) Mengkaji silabus; 2) Mengidentifikasi materi pembelajaran; 3) Menentukan tujuan; 4) Mengembangkan kegiatan pembelajaran; 5) Menjabarkan jenis penilaian; 6) Menentukan alokasi waktu; dan 7) Menentukan sumber belajar.

\section{Tujuan, Manfaat, Dan Kerangka Pemecahan Masalah}

Tujuan dari kegiatan ini adalah untuk memberikan informasi kepada guru-guru di MIS Darul Furqan Lembang mengenai penerapan kurikulum 2013, baik itu kurikulum 2013 secara umumnya, maupun secara khusus seperti pendekatan saintifik dan tiga model pembelajaran yang dianjurkan (problem based learning, project based learning, discovery learning). Selain itu, melalui kegiatan ini juga guru-guru dibimbing untuk melakukan praktik penyusunan perangkat pembelajaran, mulai dari kalender akademik, jadwal pelajaran, RPP, serta melakukan simulasi mengajar dan ice breaking. 
Manfaat yang diharapkan dari pengabdian ini adalah berikut: (1) Guru-guru MIS Darul Furqan memiliki pemahaman yang luas mengenai kurikulum 2013, pendekatan pembelajaran yang digunakan (pendekatan saintifik) dan model pembelajaran yang dianjurkan (problem based learning, project based learning, discovery learning); (2) Guru-guru MIS Darul Furqan memiliki kemampuan dan keterampilan dalam menyusun perangkat pembelajaran berdasarkan kurikulum 2013; dan (3) Guru-guru MIS Darul Furqan memiliki keterampilan dalam melaksanakan pembelajaran yang berorientasi pada keaktifan peserta didik.

Sebagai upaya dalam mengatasi permasalahan seperti yang telah disebutkan maka dilakukanlah kegiatan pelatihan kurikulum 2013. Melalui kegiatan ini diharapkan pihak sekolah termasuk guru-guru MIS Darul Furqan sebagai sasarannya lebih memahami dan mampu mengimplementasikan kurikulum 2013.

\section{METODE PELAKSANAAN}

Realisasi Pemecahan Masalah dalam pengabdian ini meliputi: (1) Bentuk kegiatan ini adalah pelatihan dengan tema "Pelatihan Kurikulum 2013"; (2) Waktu pelaksanaan, kegiatan ini dilaksanakan tanggal 21 Juli 2014 pukul 08.00-17.00 WIB; (3) Kegiatan dilaksanakan di gedung MIS Darul Furqan Lembang; (4)Penyelenggara kegiatan ini adalah MIS Darul Furqan; (5) Peserta kegiatan ini, dihadiri oleh 12 orang guru MIS Darul Furqan. (6) Narasumber dalam kegiatan adalah Diena San Fauziya, M.Pd. dan Mekar Ismayani, M.Pd.; dan (7) Sasaran kegiatan adalah guru MIS Darul Furqan Lembang.

\section{HASIL DAN PEMBAHASAN}

Dari pelaksanaan kegiatan, diperoleh hasil bahwa guru-guru sebagai peserta kegiatan begitu antusias dan aktif. Hal ini dibuktikan dengan banyaknya pertanyaan yang muncul dan diskusi berjalan multiarah. Melalui kegiatan ini pula guru-guru dibekali penyusunan perangkat pembelajaran (workshop) sehingga saat kegiatan selesai mereka memiliki produk, yakni RPP dan jadwal pelajaran (untuk sekolah/Bu Dian). Ibu Dian selaku pengundang pun memberikan respon positif dan memberikan testimoni bahwa kegiatan ini sangat membantu mereka dalam menghadapi kurikulum 2013.

\section{E. KESIMPULAN}


Simpulan yang dapat ditarik dari kegiatan ini adalah berikut.

1. Pelatihan kurikulum 2013 sangat membantu para guru dalam menghadapi dan mengimplementasikan berbagai macam kebijakan.

2. Pelatihan kurikulum 2013 menciptakan kemampuan dan keterampilan dalam menyusun RPP bagi guru.

3. Pelatihan kurikulum 2013 memberikan bekal tatacara membangun pembelajaran yang berpusat pada keaktifan siswa.

\section{F. DAFTAR PUSTAKA}

Kemendikbud. (2013a). Elemen Perubahan Kurikulum 2013. Tayangan dari Pelatihan Kurikulum di SD.

Kemendikbud. (2013b). Implementasi Pembelajaran Tematik Terpadu. Tayangan dari Pelatihan Kurikulum di SD.

Kemendikbud. (2013c). Model Pembelajaran Penemuan (Disvovery Learning). Tayangan dari Pelatihan Kurikulum di SD.

Kemendikbud. (2013d). Model Pembelajaran Berbasis Masalah (Problem Based Learning). Tayangan dari Pelatihan Kurikulum di SD.

Kemendikbud. (2013e). Pembelajaran Berbasis Proyek (Project Based Learning). Tayangan dari Pelatihan Kurikulum di SD.

Kunandar. (2013). Penilaian Autentik: Penilaian Hasil Belajar Peserta Didik Berdasarkan Kurikulum 2013. Jakarta: PT RajaGrafindo Persada.

Majid, Abdul. (2014). Pembelajaran Tematik Terpadu. Bandung: PT Remaja Rosdakarya. Sanjaya, Wina. (2012). Strategi Pembelajaran Berorientasi Standar Proses Pendidikan. Jakarta: Kencana Media Group.

Permendikbud No. 81A tentang Implementasi Kurikulum 2013. 